\title{
Stability evaluation of oilseed rape hybrids in unreplicated trials carried out in different locations
}

\author{
Bogna Zawieja ${ }^{1}$, Sylwia Lewandowska ${ }^{2}$, Tomasz Mikulski ${ }^{3}$, \\ Wiesław Pilarczyk ${ }^{1}$ \\ ${ }^{1}$ Department of Mathematical and Statistical Methods, Poznan University of Life Sciences, \\ Wojska Polskiego 28, 60-637 Poznań, Poland, e-mail: bogna.zawieja@up.poznan.pl \\ ${ }^{2}$ Wrocław University of Environmental and Life Sciences, Department of Genetics, Plant \\ Breeding and Seed Production, Plac Grunwaldzki 24A, 50-363 Wrocław, Poland, \\ sylwia.lewandowska@upwr.edu.pl \\ ${ }^{3}$ Norddeutsche Pflanzenzucht Hans Georg Lembke KG, Hohenlieth, Germany
}

\section{SUMMARY}

\begin{abstract}
An analysis is made of results from early stages of testing of promising hybrids. The data consist of single-replicate trials performed by Norddeutsche Pflanzenzucht in 6 locations (5 in Poland and one in Germany). In total 165 hybrids were tested with 3 standard varieties. The subject of the analysis was the seed yield. Three measures of stability were used. The yield of tested hybrids is expressed as percentage of that of standard varieties. Wricke's ecovalence expressed as a contribution to $\mathrm{G} \times \mathrm{E}$ interaction was used as a measure of stability. Additional characterization of the tested hybrids was performed by regressing hybrid yield on the mean yields of the experiment, as described by Finlay and Wilkinson and by Eberhart and Russel. The methods applied enabled selection of the most promising hybrids for further yield testing.
\end{abstract}

Key words: breeding, ecovalence, standard varieties

\section{Introduction}

Due to the phenomenon of heterosis, the performance of component lines is not a good indicator of yields of hybrids. Therefore, in the process of hybrid breeding, large numbers of hybrids are needed, which should be tested in different environments to identify the best ones. Recently, new genomic methods that enable selection of superior parental lines have been proposed to facilitate the choice of the best hybrid combinations. At present, however, it is difficult to 
implement them in practical breeding because their cost-effectiveness has not been evaluated (Werner, 2018). Many studies have been devoted to the identification of the best candidate varieties on the basis of series of experiments. It has been stated in several papers (Dobek et al., 2008; Annicchiarico, 2002; Woś et al., 2010) that a good method of selection of advanced breeding material is of great importance. Woś et al. (2010), after analyzing a series of single-replicate trials with several standards, reported obtaining a group of high-yielding genotypes with good performance across all environments.

A review of different methods of planning such trials and methods for their analysis (adjustment of treatment means) is given by Kempton and Fox (1997). According to the results reported by Ambroży et al. (2009a b) the method of moving averages is often the most effective. The yield of tested hybrids after adjustment by comparisons with neighboring standard varieties is an important characteristic influencing decisions to accept or reject hybrids for further stages of testing. In those stages, the accepted genotypes are tested either in replicated trials at one or several locations or in single-replicate trials repeated over several locations and with a few standard varieties sown among the tested genotypes. High and stable seed yield over all locations is an important and expected trait of elite hybrids. Only hybrids yielding higher than the mean yield of standard varieties and with yield stable over locations may be considered for selection for further testing.

Identification of the best genotypes after analysis of a one-year series of 4-5 trials is often unsatisfactory, because of the low correlation among years (Węgrzyn, 2003). Therefore, high-yielding genotypes in one-year series should be tested in the subsequent year(s). Mądry et al. (2006) showed that genotype x year interaction dominates over genotype $\mathrm{x}$ location interaction.

Unreplicated trials are used in oil-seed rape breeding trials performed by the company Norddeutsche Pflanzenzucht Hans Georg Lembke KG. In this paper a method of statistical analysis of such trials is proposed and applied to real data. In selecting genotypes at early stages of evaluation of candidate varieties 
(hybrids) two methods of measuring stability are commonly used: Wricke's ecovalence (1962) and regression analysis according to Eberhart and Russel (1966).

\section{Material and methods}

In 2017 the company Norddeutsche Pflanzenzucht Hans Georg Lembke KG performed a series of field yield trials on oil-seed rape. The trials were conducted in five locations in Poland (Falęcin, Tomaszów Bolesławiecki, Gola, Głubczyce and Krzyżewo) and in Malchow in Germany. A total of 165 hybrids and three standard varieties were tested. For technical reasons the tested hybrids were divided into five groups $(1131,1132,1133,1134,1135)$, each of 33 genotypes numbered from 1 to 33 , and each group was supplemented by the same three standard varieties (no. 34-Atora, 35-DK Exquisite and 36-Ragnar). Therefore at each location there were five "parallel" trials, each consisting of 36 treatments, sown in one replicate. Plots were arranged in several rows depending on the shape of the experimental field. Hybrids and standard varieties were randomly assigned to plots. A schematic representation of a trial is given below in Figure 1.

\begin{tabular}{|c|c|c|c|c|c|}
\hline 32 & 5 & 9 & 29 & 20 & 31 \\
\hline 21 & 26 & 30 & 10 & 1 & 13 \\
\hline 36 & 15 & 12 & 4 & 23 & 24 \\
\hline 6 & 14 & 3 & 19 & 34 & 27 \\
\hline 7 & 11 & 25 & 18 & 2 & 35 \\
\hline 22 & 16 & 17 & 28 & 33 & 8 \\
\hline
\end{tabular}

Figure 1. Example layout of a single-replicate trial with 36 treatments (33 hybrids +3 standard cultivars)

The plot sizes for harvesting were slightly unequal between locations and varied from 10.5 to $13.5 \mathrm{~m}^{2}$. After harvesting, the yield of each tested hybrid was expressed as a percentage of the mean yield of the three standards. To evaluate 
the stability of the tested hybrids, the ecovalence (W), according to Wricke (1962) and Haufe and Geidel (1978), was calculated and expressed as a percentage of the mean square for $\mathrm{G} x \mathrm{E}$ interaction, this being a measure of the contribution of each hybrid to the interaction. The ecovalence is calculated using the formula $W=x_{i j}-\bar{x}_{i}-\bar{x}_{j}+\bar{x}$, where $x_{i j}$ is the observation for the $i$-th hybrid in the $j$ th environment, $\bar{x}_{i}$ is the mean observation for the $i$-th hybrid, $\bar{x}_{j}$ is the mean for the $j$-th environment and $\bar{x}$ is the overall mean. Another approach was to apply regression analysis according to Finlay and Wilkinson (1963) and Eberhart and Russel (1966). In this approach the yield of each tested hybrid was treated as the dependent variable and the mean of all tested treatments was treated as the explanatory variable. Hybrids with slopes larger than 1 belong to the group of "intensive" hybrids, whereas those with slopes smaller than 1 belong to the group of "extensive" hybrids. The yield of intensive hybrids increases faster than the mean yield of all treatments. In selection for high-yielding hybrids the breeder should choose hybrids that (1) yield better than standard varieties, (2) have regression coefficient $\left(b_{1}\right)$ greater than unity, (3) have small deviations from the regression line (the mean square deviation or MSE is often regarded as another measure of stability), and (4) have small ecovalence.

\section{Results}

Figure 2 shows genotypes versus ecovalence and mean square deviation from regression. It can be seen that these two measures give similar results. This is also confirmed by the correlation coefficients between these two measures (1131 - 1; $1132-0.98 ; 1133-0.93 ; 1134-0.97 ; 1135-0.98$ ).

Table 1 gives the hybrids' yields (as percentages of the yield of the standard varieties), coefficients of regression $b_{i}$ and two measures of stability: ecovalence and deviation from regression ( $\left.\mathrm{S}^{2} \mathrm{di}\right)$. Of the 165 hybrids, 37 yielded higher than the standard varieties. The $b_{i}$ values ranged from 0.54 (hybrid 14 in group 1133) to 1.40 (hybrid 30 in group 1133). Most of the tested hybrids had values of $b_{i}$ close to unity (0.9-1.1). The lowest Wi value (0.13) was recorded for hybrid 33 
in group 1132, while hybrid 32 in group 1135 was the least stable, with $\mathrm{Wi}=12.58$. Values of $\mathrm{S}^{2}$ di ranged from 0.30 (hybrid 33 in group 1132) to 54.11 (hybrid 6 in group 1131).

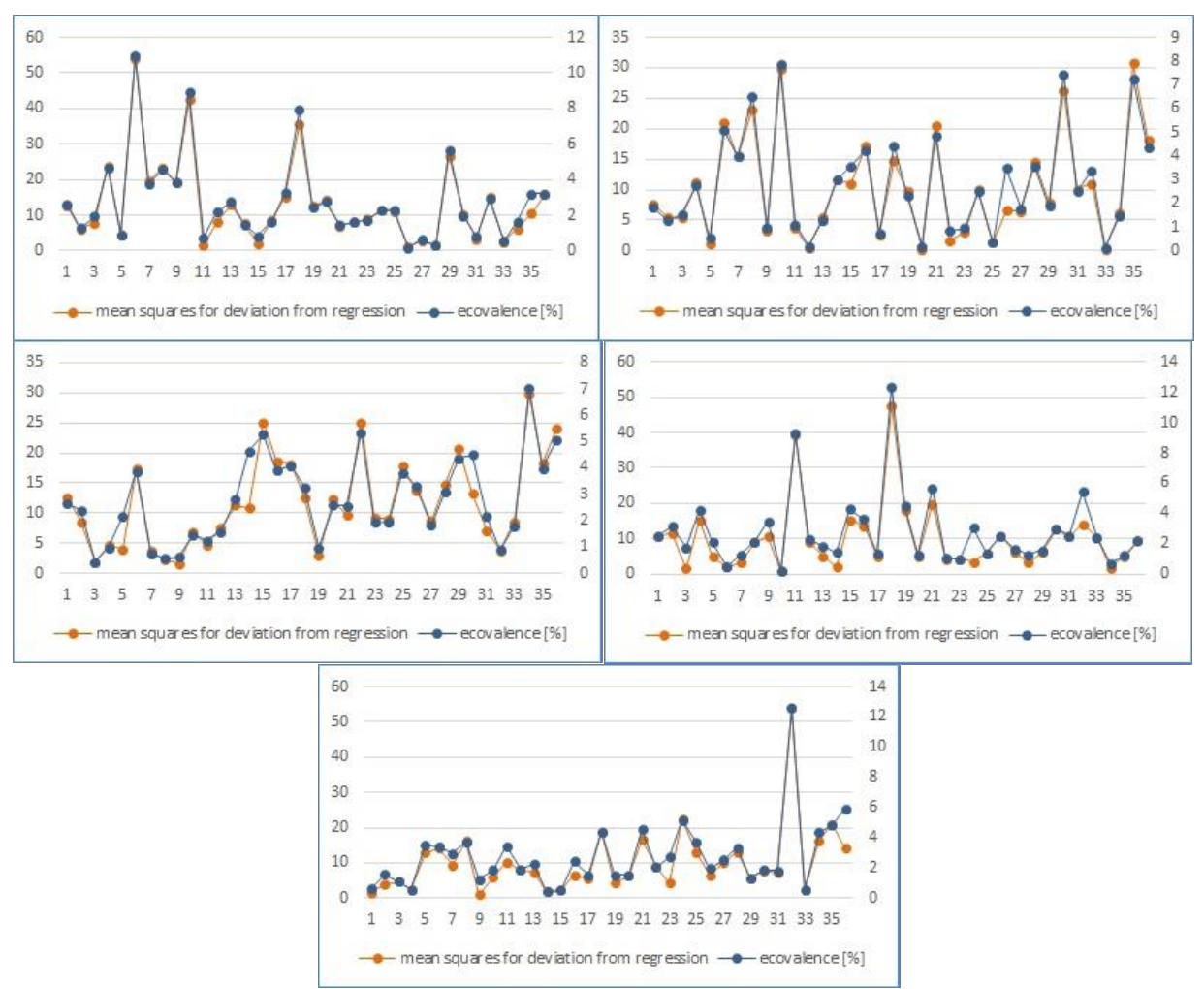

Figure 2. Genotypes versus ecovalence and mean square deviation from regression. Rows: 1131, 1132, 1133, 1134, 1135. The horizontal axis gives the number of the hybrid, the left axis the MSE, and the right axis the ecovalence

\section{Discussion and conclusions}

The results of the statistical analysis may be summarized as follows:

1. Among the 165 tested hybrids there were 21 yielding better than the mean yield of the standards and simultaneously with slope greater than 1, namely hybrid 6 in group 1131, hybrids 7, 29 and 30 in group 1132, hybrids 1, 8, 13, 22, 30 and 31 
Column A $\downarrow$

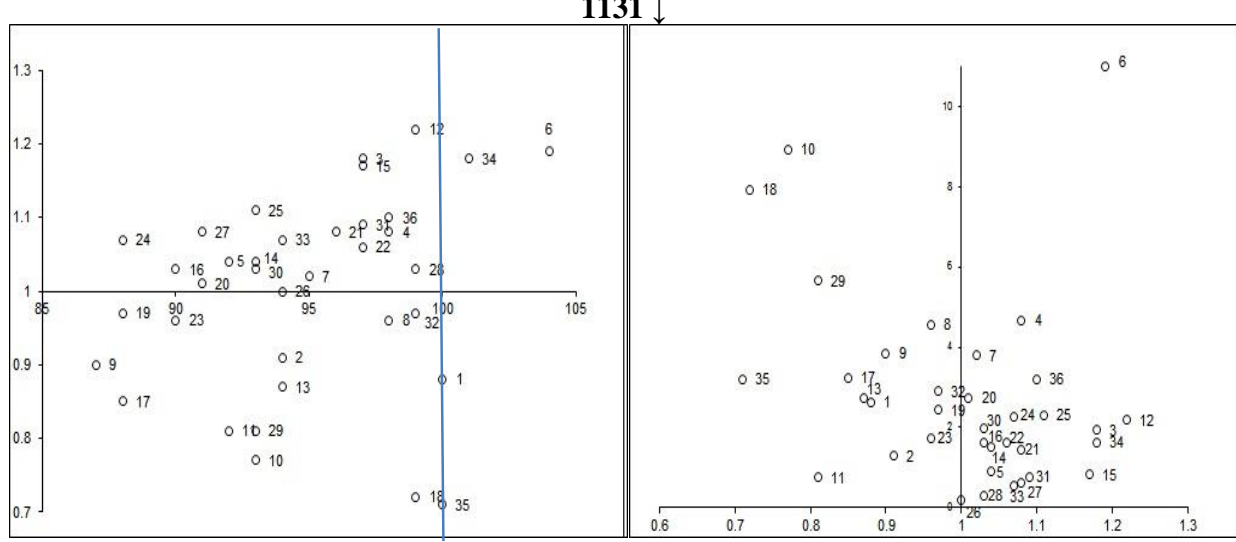

$1132 \downarrow$

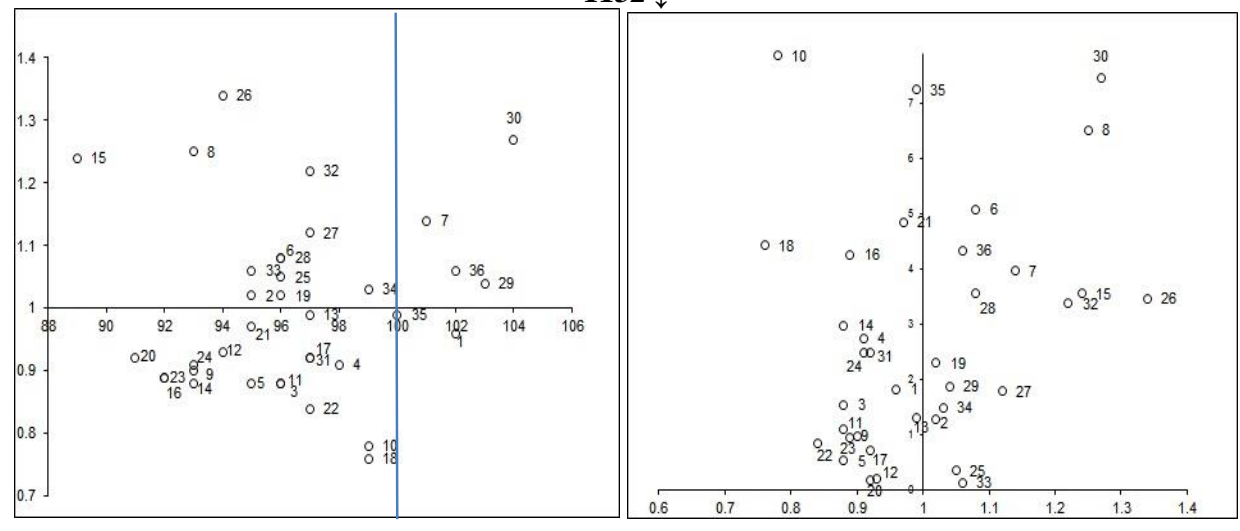

$1133 \downarrow$

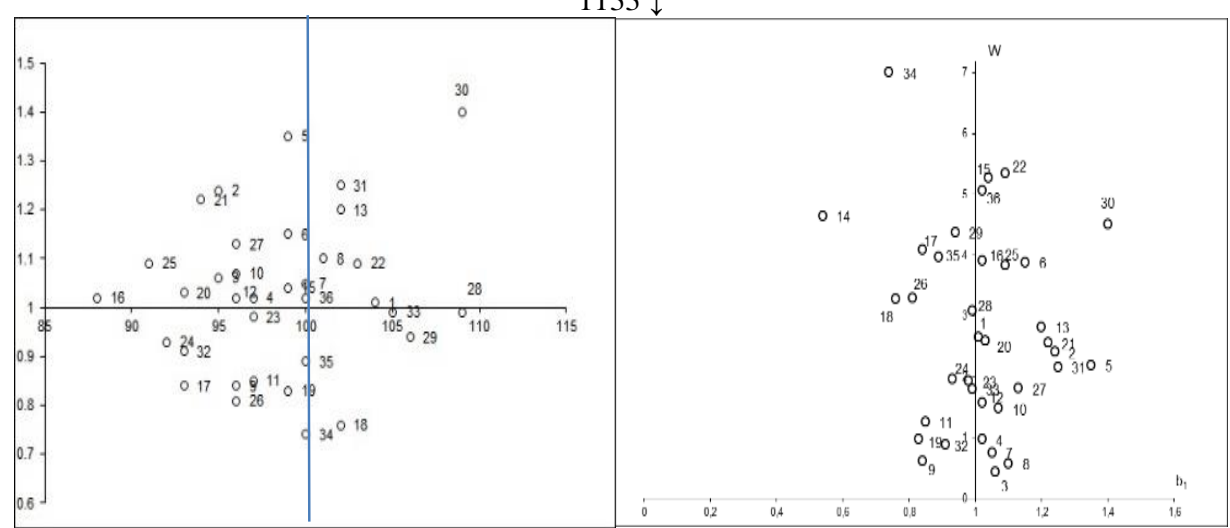



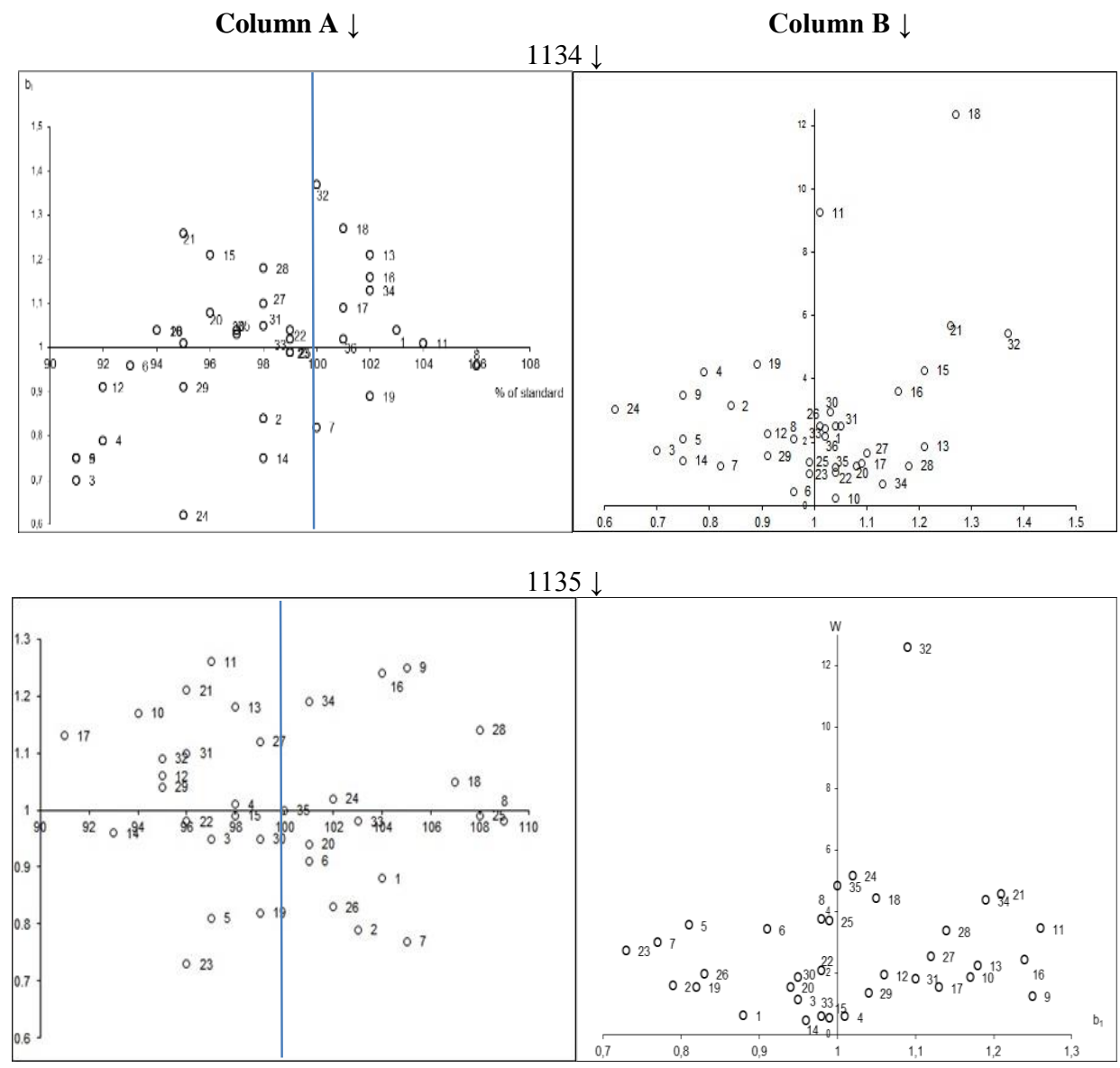

Figure 3. Column A - yield as percentage of standard varieties (horizontal axis) versus slope of linear regression (vertical axis).

Column B - slope of linear regression (horizontal axis) versus ecovalence (vertical axis).

Rows - the five groups of hybrids 1131, 1132, 1133, 1134, 1135.

The genotypes that lie in the top right area in the left panel and also in the right bottom area in the left panel are the best.

The blue line indicates $100 \%$ of the yield of the standards 
Table 1. Yield as percentage of mean yield of standard varieties, slope of linear regression, contribution (in \%) of tested hybrids to sum of squares for interaction (ecovalence), mean square deviation from regression $\left(\mathrm{S}^{2} \mathrm{di}\right)$

\begin{tabular}{|c|c|c|c|c|c|c|c|c|c|c|c|c|c|c|c|c|c|c|c|c|}
\hline & & & & & & & 152 & & & & 133 & & & & 1134 & & & & 135 & \\
\hline no & 4 & $\mathrm{R}$ & C & D & A & B & C & D & A & B & C & D & A & B & C & D & A & B & C & D \\
\hline 1 & 100 & 88 & 64 & 9 & 2 & 0.96 & 1.82 & 2 & 104 & 1.01 & 2.65 & 62 & 103 & 1.04 & 2.50 & 58 & 4 & 88 & 61 & 6 \\
\hline 2 & 94 & 91 & .29 & 6.18 & 95 & 1.02 & 1.27 & 5.34 & 95 & 4 & - & - & 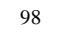 & . & 15 & 55 & 3 & 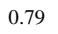 & 57 & . \\
\hline 3 & 97 & 1.18 & 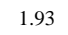 & 7.74 & 0 & 0.88 & 1.54 & & 95 & 1.06 & o. & 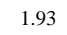 & - & & 1.10 & 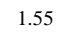 & (1) & 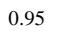 & 11 & 4.64 \\
\hline 4 & 98 & OO & 8 & .77 & 98 & 0. & 2. & 1 & 97 & 2 & 0.97 & 0 & 92 & & 4 & 15.23 & 98 & 1 & 57 & .47 \\
\hline 5 & 92 & 04 & 92 & 63 & 95 & 0.88 & 0.53 & 1.23 & 99 & 1.35 & 2.19 & 4.04 & 91 & 0.75 & 2.09 & 4.76 & 97 & .81 & .55 & 13.03 \\
\hline 6 & 104 & 1.19 & 10.98 & .11 & 6 & 1.08 & 5.08 & 21.08 & 99 & 1.15 & 3.88 & 17.33 & 93 & 0.96 & 0.46 & 1.87 & 101 & 0.91 & 3.41 & 4.24 \\
\hline 7 & 95 & .02 & 3.80 & 62 & 101 & 1.14 & 3.97 & 15.46 & 100 & 1.05 & 0.75 & 22 & 100 & 0.82 & 1.26 & 3.19 & 05 & 77 & .98 & 9.43 \\
\hline 8 & 98 & 6 & 56 & 23.44 & 93 & 1. & 6. & 23 & 101 & 0 & 0. & 4 & 106 & 0. & 2 & 6 & 9 & 8 & 74 & 16.19 \\
\hline 9 & 87 & 0.90 & 3.85 & 15 & 30 & 0.90 & 0.97 & 3.40 & 96 & 0.84 & 0.61 & 1.61 & 91 & 0.7 & 3.49 & 10.65 & 105 & 1.25 & 1.24 & 1.04 \\
\hline 10 & 93 & 0.77 & 8.93 & 42.54 & 99 & 0.78 & 7.87 & 29.79 & 96 & 1.07 & 1.48 & 6.83 & 94 & 1.04 & 0.22 & 0.83 & 94 & 1.17 & 85 & 04 \\
\hline 11 & 92 & 0.81 & 0.76 & 43 & 96 & 0.88 & 1.11 & 3.67 & 97 & 0.85 & 1.26 & 4.77 & 104 & 1.01 & 9.25 & 39.58 & 97 & 1.26 & 3.44 & 0.37 \\
\hline 12 & 99 & 22 & 19 & 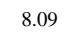 & 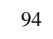 & 0.93 & 0.20 & 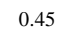 & 96 & 1.02 & 1.57 & 7.49 & 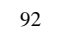 & 0.9 & 2.27 & 9.1 & 95 & 1.06 & 1.93 & 8.10 \\
\hline 13 & 94 & 87 & 2.74 & . 07 & 3 & 0.99 & 1.30 & 5.53 & 102 & 1.20 & 2.82 & 11.32 & 102 & 1.21 & 1.86 & 5.05 & 98 & 10 & 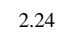 & 7.36 \\
\hline 14 & 93 & 04 & .50 & 60 & 93 & 0.88 & 2.98 & 11.63 & 100 & 0.54 & 4.65 & 10.87 & 98 & 0. & 1.43 & 10 & 93 & 96 & 0.45 & 1.86 \\
\hline 15 & 97 & 1.17 & 0.82 & 2.08 & 89 & 1.24 & 3.56 & 11.07 & 99 & 1.04 & 5.28 & 25.07 & 96 & 1.21 & 4.28 & 15.34 & 98 & 99 & 0.52 & 2.24 \\
\hline 16 & 90 & 1.03 & 1.63 & 8.36 & 92 & 0.89 & 4.26 & 17.22 & 88 & 1.02 & 3.91 & 18.62 & 102 & 1.16 & 3.60 & 13.75 & 104 & 1.24 & 2.43 & 6.66 \\
\hline 17 & 88 & 85 & 3.25 & 22 & 97 & 0.92 & 0.72 & 2 & 93 & 0.84 & 4.09 & 8.12 & 101 & 1.09 & 1.32 & 5.11 & 91 & 13 & 52 & 5.46 \\
\hline 18 & 99 & 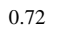 & 7.93 & 35.58 & 99 & 0. & 4. & 14 & 102 & 6 & 8 & 12.66 & 1 & 1.27 & 12.36 & .81 & 7 & 5 & 11 & 18.98 \\
\hline 9 & 88 & & & & 96 & & & & 99 & & & & 2 & 0 & & 18.27 & 99 & & 1.54 & 4.50 \\
\hline 20 & 91 & 1.01 & 2.74 & .18 & 91 & 0.92 & 0.18 & 0.29 & 93 & 1.03 & 2.60 & 12.33 & 96 & 1. & .25 & 4.92 & 101 & 94 & .53 & 42 \\
\hline 21 & 96 & 1.08 & 1.46 & 7.11 & 95 & 0.97 & 4.86 & 20.52 & 94 & 1.22 & 2.56 & 9.70 & 95 & 1.26 & 5.68 & 19.86 & 96 & 1.21 & 4.56 & 6.60 \\
\hline 22 & 97 & 1.06 & 1.61 & 810 & 97 & 0.84 & 0.83 & 1.69 & 103 & 1.09 & 5.35 & 25.07 & 99 & 1.0 & 1.03 & 4.30 & 96 & 0.98 & 2.07 & 96 \\
\hline 23 & 90 & 96 & 17 & 8.85 & 92 & 0. & 0.9 & 3 & 97 & 0.98 & 193 & 9.17 & 99 & 0. & 100 & 429 & 96 & 3 & 13 & 434 \\
\hline 24 & 88 & 1.07 & 2 & & 93 & 0 & 2 & & 92 & 3 & 1.96 & & 95 & & 3.05 & 4 & 2 & 1.02 & 5 & 22.34 \\
\hline 25 & 93 & 1.11 & 2. & .04 & 96 & 1. & & & 91 & 9 & & 17.80 & 9 & & & 5 & 8 & 0.99 & 88 & 15.02 \\
\hline 26 & 94 & 1 & 0. & 0.98 & 94 & 1. & 3 & 6.60 & 96 & 0.81 & 0 & 0 & 95 & 1. & .52 & 10.77 & 102 & 3 & .97 & 60 \\
\hline 27 & 91 & 1.08 & 0.64 & 2.82 & 97 & 1.12 & 1.78 & 6.42 & 96 & 1.13 & 1.81 & 75 & 98 & 1.10 & 1.65 & 6.35 & 99 & 1.12 & 2.54 & 10.09 \\
\hline 28 & 99 & 1.03 & 0.3 & 1.51 & 96 & 1.08 & 3.56 & 14.64 & 109 & 0.99 & 3.09 & 1 & 98 & 1.1 & 1.27 & 3.18 & 108 & 1.14 & 3.36 & 3.18 \\
\hline 29 & 93 & 088 & 5 & 6.76 & & 1. & 1. & & 5 & 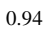 & 3 & 20.68 & 95 & 0.91 & 1.57 & & 95 & & 135 & \\
\hline 30 & 93 & 1.03 & 1.99 & 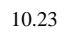 & 104 & 1. & 7. & 2 & 1 & 0 & & 13.28 & 7 & 1.03 & 3 & 12.69 & 9 & 5 & 1.85 & 7.87 \\
\hline 31 & 97 & 1 & 0 & & 97 & 0. & 2. & 10 & 102 & 5 & 2.16 & & 8 & 1 & 3 & 3 & 96 & 0 & 80 & 7.11 \\
\hline 32 & 99 & 0.97 & 2.90 & .97 & 97 & 1.22 & 3.38 & 11.00 & 93 & 0.91 & 0.88 & 76 & 100 & 1. & 5.43 & .14 & 95 & 1.09 & 12.58 & 54.05 \\
\hline 33 & 94 & 1.07 & 0.55 & 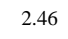 & 95 & 1.06 & 0.13 & 0.30 & 105 & 99 & 1.80 & 8.57 & 9 & 1.0 & 43 & 10.39 & 103 & 98 & 9 & .54 \\
\hline 34 & 01 & 1.18 & 1.64 & 09 & 99 & 1.03 & 1.49 & 6.26 & 100 & 0.74 & 7.01 & 29. & 102 & 1. & 0.70 & 1.76 & 101 & 1.19 & 4.36 & 1 \\
\hline 35 & 00 & 0.71 & 3.20 & 50 & 100 & 0.9 & 7.25 & 3 & 100 & 9 & 30 & 10 & 97 & 1.04 & 12 & 5.11 & 00 & 00 & 2 & 20.93 \\
\hline 36 & 98 & 1.10 & 1 & 84 & 102 & 1.06 & 4. & 18.17 & 100 & 1.02 & 77 & 4.15 & 101 & 1.02 & 2.17 & 9.26 & 99 & 0.59 & 5.96 & 4. \\
\hline & & & & & & & & & & & & & & & & & & & & \\
\hline
\end{tabular}


in group 1133, hybrids 1, 11, 13, 16, 17 and 18 in group 1134, and hybrids 9, 16, 18, 24 and 28 in group 1135.

2. Among these the highest yield was attained by hybrid 30 in group 1133 (109\%), but this hybrid had high deviation from regression and high ecovalence. 3. Among those listed above, the most interesting from the point of view of yield stability (low contribution to $\mathrm{G} x \mathrm{E}$ interaction and low deviation from regression) are hybrid 29 from group 1132, hybrid 8 from group 1133, hybrids 13 and 17 from group 1134, and hybrid 9 from group 1135.

4. Hybrid 9 from group 1135 gave the highest yield among those listed above.

5. In studies on the stability of cultivars, either the $S^{2}$ di of Eberhart and Russel or Wricke's ecovalence can be used.

The best method to determine the differences between genotypes is to evaluate them in field trials. Unfortunately, it is not easy to find a field with homogeneous soil; therefore a breeder has to lay out the promising lines in blocks without soil heterogeneity. In practice it is difficult to carry out trials with a large number of genotypes (advanced breeding lines). Hence, in early stages of line evaluations, the experiments are unreplicated and conducted in only one location, and the error variance is controlled using check plots (standard varieties). Therefore, the question arises whether in unreplicated trials there is a loss of precision in comparing entries. In the early stages of plant breeding genetic gain can be increased more successfully by testing a large number of genotypes than by making more precise comparisons of fewer entries (Bos, 1983; Gauch and Zobel, 1996). Thus, in practice, unreplicated trials can provide an acceptable means of screening a large number of candidate varieties. Another challenge which confronts the breeder is genotype $\mathrm{x}$ environment interactions, which are important sources of variation that hinder the identification of the best genotypes. Selections with minimal variance for yield across different environments are considered stable. This concept of stability is called static or biological, but it is not acceptable in modern crop production, which prefers genotypes with high mean yields and the potential to respond to better environmental conditions 
(Becker, 1981). Breeders prefer a dynamic concept of stability with high yield performance of released varieties (Becker and Leon, 1988).

There are many measures of stability, but the most common is the joint regression analysis of Eberhart and Russel (1966) and Wricke (1962). The measures Wi and $S^{2}$ di are strongly correlated, so for the purpose of ranking genotypes they give more or less the same results. However, Eberhart and Russel's method gives the parameter $b_{i}$, which enables the identification of cultivars adapted to low- or high-yielding locations. Hybrids with $b_{i}$ less than 0.7 are better adapted to low-yielding locations, whereas those with values greater than 1.3 are more responsive to high-yielding locations (Lin and Binns, 1988). Thus, hybrid 14 in group 1133 (0.54), hybrid 3 in group 1134 (0.70), hybrid 24 in group $1134(0.62)$ and hybrid 23 in group $1135(0.73)$ are better adapted to low-yielding environments, while hybrids 26 (1.34) and 30 (1.27) in group 1132, hybrids 5 (1.35) and 30 (1.30) in group 1133, and hybrid 32 in group 1134 (1.37) are responsive to better environmental conditions. The highest yields were attained by hybrid 30 in group $1133\left(\mathrm{~b}_{\mathrm{i}}=1.40\right)$ and hybrid 28 in group 1135 $\left(b_{i}=1.14\right)$, but the latter is less responsive to better environments. There is a close correlation between the $\mathrm{S}^{2} \mathrm{di}$ of Eberhart and Russel and the ecovalence of Wricke. Similar results were reported by Mohammadi and Ahmed (2008) and Becker (1981).

It can be concluded that ecovalence, because of its simplicity of calculation, would be preferred as a measure of stability by those breeders who do not have easy access to higher software functionality. However, a breeder wishing to know a cultivar's responsiveness to a specific environment will have to estimate $b_{i}$.

\section{REFERENCES}

Ambroży K., Bakinowska E., Bocianowski J., Budka A., Pilarczyk W., Zawieja B. (2008a): Statystyczne wspomaganie decyzji selekcyjnych na wczesnych etapach hodowli zbóż. I. Metody oceny efektów obiektowych [Statistical support of selection decisions at early stages of cereal breeding. Part I. Methods of estimation of treatment effects], Biuletyn IHAR, 250: 21-28.

Ambroży K., Bakinowska E., Bocianowski J., Budka A., Pilarczyk W., Zawieja B. (2008b): Statystyczne wspomaganie decyzji selekcyjnych na wczesnych etapach 
hodowli zbóż. II. Empiryczne porównanie metod oceny efektów obiektowych [Statistical support of selection decisions at early stages of cereal breeding Part II. Empirical comparison of treatment effects estimation methods]. Biuletyn IHAR, 250: 29-40.

Annicchiarico P. (2002): Genotype $\times$ Environment Interactions-Challenges and Opportunities for Plant Breeding and Cultivar Recommendations. FAO, Rome. Plant Production and Protection Paper, 174.

Becker H.C., Leon J. (1988): Stability analysis in plant breeding. Plant Breeding 101: $1-23$.

Becker H.C. (1981): Correlations among some statistical measures of phenotypic stability. Euphytica 30: 835-840.

Bos J. (1983): The optimum number of replications when testing lines or families on a fixed number of plots. Euphytica 32: 311-318.

Dobek A., Bocianowski J., Bakinowska E., Pilarczyk W., Mikulski W., Kaczmarek J. (2008): Problemy związane z testowaniem linii i rodów zbóż na wczesnych etapach hodowli [Problems related to testing of cereal lines at early stages of plant breeding]. Biuletyn IHAR, 249: 29-34.

Eberhart S.T., Russel W. (1966): Stability parameters for comparing varieties. Crop Science 6:.36-40.

Finlay K.W., Wilkinson G.N. (1963): The analysis of adaptation in a plant breeding programme. Australian Journal of Agricultural Research 14: 742-754.

Gauch H.G., Zobel R.W. (1996): Optimal replication in selection experiments. Crop Science 36: 838-843.

Haufe W., Geidel H. (1978): Beurteilung der Ertragsicherkeit von Sorten und Zuchtstamen. Definitionen, Stabilitatsparameter und deren Interpretationsmoglichkeiten. Z. Pflanzenzuchtung 80: 24-37.

Kempton R.A., Fox P.N. (1997): Statistical methods for plant variety evaluation. Chapman \& Hall.

Lin C.S., Binns M.R. (1988): A superiority measure of cultivar performance for cultivar x location data. Can. J. Plant Sci. 68: 193-198.

Mohammadi R., Ahmed A. (2008): Comparison of parametric and non-parametric methods for selecting stable and adapted durum wheat genotypes in variable environments. Euphytica 159: 419-432.

Mądry W., Talbot M., Ukalski K., Drzazga T., Iwańska M. (2006): Podstawy teoretyczne znaczenia efektów genotypowych i interakcyjnych w hodowli roślin na przykładzie pszenicy ozimej [Theoretical basis of importance of genotypic and interaction effects in plant breeding using the example of winter wheat]. Buletyn IHAR 240/241:13-32.

Werner R., Lunwen Q., Voss-Fels K.P., Abbadi A., Leckband G., Frisch M., Snowdon R. (2018): Genome-wide regression models considering general and specific combining ability predict hybrid performance in oilseed rape with similar accuracy regardless of trait architecture. Theoretical and Applied Genetics 131: 299-317.

Węgrzyn S. (2003): Ocena genotypowo-statystyczna wyników doświadczeń polowych z rodami hodowlanymi na przykładzie pszenicy ozimej [A genotypic-statistical evaluation of the results of field experiments with breeding lines using the example of winter wheat]. Biuletyn IHAR 230: 29-42. 
Woś H., Adamska E., Kaczmarek Z. (2010): Metody statystyczne dla oceny mieszańców i ich linii rodzicielskich na podstawie serii doświadczeń jednopowtórzeniowych z wzorcami [Statistical methods for evaluation of hybrids and their parental lines on the basis of a series of unreplicated experiments with standards]. Rośliny Oleiste Oilseed Crops 31: 243-256.

Wricke G. (1962): Uber eine Methode zur Erfassung der okologischen streubreite im Feldversuchen. Z. Pflanzenzucht 47: 92-96. 